\title{
Sediment properties and bacterial community in burrows of the ghost shrimp Pestarella tyrrhena (Decapoda: Thalassinidea)
}

\author{
Sokratis Papaspyrou ${ }^{1, *}$, Trine Gregersen ${ }^{2}$, Raymond P. Cox ${ }^{2}$, \\ Maria Thessalou-Legaki ${ }^{1}$, Erik Kristensen ${ }^{3}$
}

${ }^{1}$ Department of Zoology-Marine Biology, Faculty of Biology, University of Athens, Panepistimiopolis, 15784 Athens, Greece

${ }^{2}$ Department of Biochemistry and Molecular Biology, and ${ }^{3}$ Institute of Biology, University of Southern Denmark, 5230 Odense M, Denmark

\begin{abstract}
Chemical properties of burrow wall sediment from burrows of the thalassinidean shrimp Pestarella (=Callianassa) tyrrhena located at Vravrona Bay (Aegean Sea, Greece) were studied and found to be very different from the sediment surface and ambient anoxic sediment. P. tyrrhena burrow walls had significantly higher amounts of silt and clay, while total organic carbon (TOC) was up to 6 times higher than in surrounding sediment. Chlorophyll a (chl a) accounted for a small fraction of TOC and showed similar values in burrow walls and surface sediment, whereas the low chl $a$ : $\mathrm{chl} a+$ phaeopigment ratio indicated the presence of more fresh material in the latter. Biopolymers (carbohydrates, proteins and lipids) were 4 to 11 times higher in burrow walls than in the surrounding sediment, accounting for $47 \%$ of TOC. The low protein:carbohydrate ratio indicated that the high TOC in the burrow walls was caused by the presence of aged detritus of low nutritional quality, such as seagrass detritus. The distinct conditions along the burrow wall also affected the bacterial community and resulted in a 10-fold increase of bacterial abundance. Molecular fingerprints of the bacterial communities showed that the bacterial composition of the burrow wall was more similar to the ambient anoxic sediment and showed less seasonal change than the sediment surface. These results suggest that burrow walls have distinct properties and should not be considered merely as a simple extension of the sediment surface.
\end{abstract}

KEY WORDS: Bioturbation · Organic matter · Seagrass detritus $\cdot$ Bacteria $\cdot$ PCR-DGGE $\cdot$ Pestarella tyrrhena

Resale or republication not permitted without written consent of the publisher

\section{INTRODUCTION}

Biogenic structures, such as tubes and burrows, are a ubiquitous feature of aquatic environments. Tubes and burrows are semi-permanent or permanent structures that differ in size, appearance and composition according to the feeding habits, mode of life, mobility, as well as the size of infaunal species (Meadows 1991). Burrows range in length from a few $\mathrm{mm}$ (meiofauna) to several meters (large polychaetes and crustaceans). They may have vertical or horizontal orientation, be branched or straight, and have either simple or com- plex structures (Griffis \& Suchanek 1991, Ziebis et al. 1996, Dworschak 2001).

The burrow environment is usually very distinct and differs from other parts of the sediment (surface and ambient anoxic sediment). Burrow walls are often rich in organic matter of variable reactivity depending on its origin, chemical composition, structure and age (Aller \& Aller 1986, Reichardt 1988, de Vaugelas \& Buscail 1990). The low diffusivity of burrow linings, when present, reduces transport of solutes between the sediment and the burrow lumen, while the usually intermittent pattern of animal irrigation promotes very variable oxygen con- 
ditions in the burrows (Kristensen 1988, Ziebis et al. 1996, Furukawa 2001). The availability of labile organic matter combined with steep chemical gradients and narrow redox zonation has a significant impact on the chemical and biological composition of the burrow environment. Bacterial abundances have been shown to be higher along burrow walls compared to either surface or ambient sediment (Aller \& Aller 1986, Branch \& Pringle 1987, Dworschak 2001). In addition, burrow walls show increased heterotrophic activity by both aerobic and anaerobic bacteria, resulting in increased rates of organic matter decomposition (Aller \& Aller 1986, Reichardt 1988, Gribsholt et al. 2003).

Thalassinidean ghost shrimps have been recognised in recent years as one of the most effective bioturbating groups of macrofaunal organisms, with significant impacts on the benthic environment (Griffis \& Suchanek 1991, Reise 2002). Pestarella tyrrhena is an important bioturbator, commonly found in muddy and fine sandy intertidal and shallow subtidal coastal sediments, where it often creates dense monospecific populations. It is a selective deposit feeder that constructs deep and complex burrows, constantly digging new branches or filling up existing ones (Dworschak 1987). P. tyrrhena increases the organic matter content in the sediment and benthic metabolism by incorporating organic detritus, such as seagrass debris, in burrow chambers (Dworschak 1987, 2001, Papaspyrou et al. 2004). In addition, it has been proposed that $P$. tyrrhena consolidates the burrow walls with mucus (Dworschak 1983, 1998). However, detailed studies have not been made on the effect of $P$. tyrrhena on the distribution and composition of organic matter associated with the burrow, or its effects on the sediment microbial community.

The aims of this study were to investigate the abiotic and biotic burrow environment of Pestarella tyrrhena and to determine how sediment properties along burrow walls differ from the surroundings. For this purpose, we collected seasonal samples from burrow walls, surface sediment and anoxic sediment, to determine particle size distribution, total organic carbon (TOC) content and relative contributions of major organic compounds (proteins, carbohydrates and lipids), and phytopigments. In addition we studied the bacterial communities in burrow walls and the surrounding sediment by measuring bacterial abundance and obtaining molecular fingerprints of the bacterial community based on 16S rRNA gene sequences.

\section{MATERIALS AND METHODS}

Study site. Sample collection was conducted in a small $\left(0.26 \mathrm{~km}^{2}\right)$ intertidal-shallow subtidal sandflat at Vravrona Bay, Aegean Sea, Greece (37 $56^{\prime} \mathrm{N}$, $\left.24^{\circ} 01^{\prime} \mathrm{E}\right)$. The coast is lined by salt marshes and a seasonal stream discharges near the head of the bay. The tidal amplitude in the area ranges from 10 to $30 \mathrm{~cm}$ and the largest part of the flat is exposed to the air during spring low tides. The sediment in the sandflat consists mainly of moderately sorted medium to fine sand with a median particle size of $0.2 \mathrm{~mm}$ and organic matter content of $2.2 \%$. The macrophyte vegetation is characterised by scattered occurrence of the seagrass Cymodocea nodosa. Dead leaves of another seagrass, Posidonia oceanica, are continuously transported into the area from deeper waters. Mean salinity in the area ranges from 20 to $39 \%$ during the year and water temperature from 11 to $29^{\circ} \mathrm{C}$.

Pestarella tyrrhena is the most abundant large bioturbator in the intertidal and shallow subtidal area and shows a mean yearly population density of $63 \pm 9$ ind. $\mathrm{m}^{-2}$, and a maximum of 144 ind. $\mathrm{m}^{-2}$ (Thessalou-Legaki 1987). It occurs in the middle part of the sandflat, avoiding both the wave-exposed seaward front and the muddier inshore salt marsh fringe that is characterised by large salinity variations (Thessalou-Legaki 1987). The diversity and abundance of other benthic macrofauna are generally low (A. Nicolaidou \& M. Thessalou-Legaki unpubl. data).

Sediment sampling. Sediment samples were collected at low tide in November 2001, and January, April and August 2002. Samples were collected from 3 different compartments associated with Pestarella tyrrhena burrows using a stainless steel spatula: burrow walls, anoxic subsurface sediment adjacent to the burrows (referred to as 'ambient') and the sediment surface. Undisturbed surface sediment was retrieved to a depth of 1 to $2 \mathrm{~mm}$. Burrow wall and ambient sediment were sampled from 5 to $20 \mathrm{~cm}$ below the surface after exposing burrows by digging. The burrow wall, defined as the layer with a clearly visible difference in colour and texture from adjacent sediment, corresponding to a radial distance of 1 to $2 \mathrm{~mm}$, was recovered first. Subsequently, the surrounding ambient sediment was collected at the same depth, but away from the burrow. Sediment material was collected from at least 5 different burrows, pooled together and analysed in triplicate, with the exception of bacterial abundance and particulate iron pool analyses which were performed on samples from individual burrows (see later).

Samples for determination of the sediment physicochemical characteristics were stored in acid-washed Eppendorf tubes $(10 \% \mathrm{HCl}$ overnight, rinsed with Milli-Q water) and kept on ice until return to the laboratory, where they were immediately frozen at $-80^{\circ} \mathrm{C}$ and subsequently freeze-dried. Samples for bacterial DNA extraction were collected in sterile Eppendorf tubes using a sterile stainless-steel spatula, kept on ice and stored at $-80^{\circ} \mathrm{C}$ until analysis. 
Samples for determination of bacterial abundance were taken in January and August 2002. Approximately $300 \mathrm{mg}$ sediment from a single burrow was transferred to a pre-weighed sterile Eppendorf tube containing $1 \mathrm{ml}$ filtered $(0.2 \mu \mathrm{m}$ filter $) 2 \%$ glutaraldehyde in seawater and stored at $4^{\circ} \mathrm{C}$ until analysis. Sediment samples for measurement of particulate iron pools were taken from sediment cores collected in January 2002 using 8 cm (internal diameter) plexiglas tubes. The cores were kept in a water tank with oxygenated water at in situ temperature and transported to the laboratory. Cores were split in 2 to expose individual burrows and samples were collected as described earlier.

Granulometry. Grain size analysis of sediment was carried out according to Buchanan (1984). Sediment subsamples were also examined for wet density (weight of a known volume) and water content (weight loss after drying at $105^{\circ} \mathrm{C}$ for $6 \mathrm{~h}$ ).

Organic content. Sediment organic matter (loss-onignition; LOI) was determined as the weight loss after combustion of dried sediment at $520^{\circ} \mathrm{C}$ for $6 \mathrm{~h}$. TOC was measured by the wet oxidation technique (Nelson \& Sommers 1975). Particulate organic nitrogen (PON) content was analysed using a Carlo Erba EA1108 CHN Elemental Analyser according to Kristensen \& Andersen (1987).

Biopolymers. Protein content (PRT) was determined according to Rice (1982) and expressed as bovine serum albumin equivalents. Carbohydrates (CHO) were measured according to Gerchakov \& Hatcher (1972) and expressed as glucose equivalents. Total lipid content (LPD) was determined after extraction by direct elution with chloroform-methanol (Bligh \& Dyer 1959, Marsh \& Weinstein, 1966) and reported as tripalmitine equivalents. Proteins, carbohydrates and lipids were converted to carbon equivalents using conversion factors of $0.49,0.40,0.75 \mathrm{~g} \mathrm{C} \mathrm{g}^{-1}$ respectively, based on the corresponding standard compounds used (Pusceddu et al. 1999). The biopolymeric fraction (BPL) was defined as the sum of carbohydrate, protein and lipid carbon. Combusted sediment $\left(520^{\circ} \mathrm{C}, 6 \mathrm{~h}\right)$ from each sediment type was used as blank samples.

Microphytobenthos. Chlorophyll a ( $\mathrm{chl}$ a) and phaeopigments (phaeo) were determined by the acetone extraction method (Parsons et al. 1984). Five $\mathrm{ml}$ of $90 \%$ acetone were added to about $0.5 \mathrm{~g}$ of sediment and left overnight at $5^{\circ} \mathrm{C}$. After shaking and centrifugation the concentration was determined spectrophotometrically at 665 and $750 \mathrm{~nm}$ before and after addition of one drop of $10 \% \mathrm{HCl}$ (Parsons et al. 1984). Chloroplastic pigment equivalents (CPE) were calculated as the sum of chl $a$ and phaeo concentrations. In order to estimate the microphytobenthic carbon, chl a concentrations were converted to carbon content using a conversion factor of 40 (De Jonge 1980).
Particulate iron. Samples for particulate iron analysis were analysed according to the colorimetric method of Lovley \& Phillips (1987). Briefly, $300 \mathrm{mg}$ of sediment was immediately transferred after collection to $5 \mathrm{ml}$ of $0.5 \mathrm{M} \mathrm{HCl}$ and extracted for $30 \mathrm{~min}$. Subsamples of the extractant were added to Ferrozine for Fe(II) determination. Total reactive Fe was determined after reduction of $\mathrm{Fe}$ (III) by hydroxylamine hydrochloride to Fe(II) in a parallel sample and analysed with Ferrozine. Reactive Fe(III) was defined as the difference between total Fe and Fe(II) (Kostka \& Luther 1994).

Bacterial counts. Total bacterial abundance was estimated by the DAPI (4'6-diamidino-2-phenylindole) counting method (Porter \& Feig 1980) as adapted by Andresen \& Kristensen (2002).

Statistical analysis. Differences between sediment types were tested by the non-parametric KruskalWallis test. In the case where analyses were performed on pooled samples seasonal data were used as replicates. Bacterial abundance was also tested for seasonal differences. Spearman-rank correlation analysis was performed to test for possible relationships between investigated variables.

DNA extraction. Sediment samples for DNA extraction were thawed and mixed thoroughly before extraction using enzymatic treatment and phenol extraction method (Ausubel et al. 1995). Approximately $300 \mathrm{mg}$ of material were suspended in $180 \mu$ l of lysis buffer (20 mM Tris, 2 mM EDTA, 1.2\% Triton, pH 8.0 with $\mathrm{HCl}$ ) and vortexed for $2 \mathrm{~min}$. Lysozyme was added at a final concentration of $0.4 \mu \mathrm{g} \mathrm{l}^{-1}$ and the suspension was incubated at $37^{\circ} \mathrm{C}$ for $30 \mathrm{~min}$. After the addition of $15 \mu \mathrm{l}$ of Proteinase K solution and $200 \mu \mathrm{l}$ AL-buffer (Qiagen DNA Stool Kit), tubes were incubated at $65^{\circ} \mathrm{C}$ for $30 \mathrm{~min}$. DNA was purified by phase-separation with a buffered solution ( $\mathrm{pH}$ 7.9) of phenol:chloroform: isoamylalcohol $(25: 24: 1)$. After precipitation with icecold isopropanol overnight at $-20^{\circ} \mathrm{C}$, the DNA was washed in cold $70 \%$ ethanol, dried, redissolved in $30 \mu \mathrm{l}$ of Milli-Q water and stored at $-80^{\circ} \mathrm{C}$. Four replicate tubes were used per sediment type and the extracted DNA was then pooled.

DNA was further purified using a Sepharose 4B column (Miller 2001). Briefly, Sepharose 4B was packed by gravity in a $2.5 \mathrm{ml}$ syringe to a final volume of $2 \mathrm{ml}$. The column was equilibrated with 4 volumes of high salt TE buffer (100 mM NaCl, $10 \mathrm{mM}$ Tris, 1 mM EDTA; pH 8.0 with $\mathrm{HCl}$ ). Crude DNA extract were added to the column followed by several additions of $0.2 \mathrm{ml}$ high salt TE buffer. The eluate was collected in $0.2 \mathrm{ml}$ fractions. The fractions giving PCR products were pooled and frozen at $-80^{\circ} \mathrm{C}$.

PCR reaction. Each PCR reaction was performed in a total volume of $20 \mu$ l. Reaction mixtures contained final concentrations of $1 \times$ PCR buffer (Amersham Pharma- 
cia Biotech); BSA $0.5 \mu \mathrm{g} \mu \mathrm{l}^{-1}$; deoxynucleoside triphosphate solution (200 $\mathrm{\mu M}$ each); universal bacterial primers; GC-341f (5' CGC CCG CCG CGC CCC GCG CCC GGC CCG CCG CCC CCG CCC CCC TAC GGG AGG CAG CAG 3') (Muyzer et al. 1993, Overmann \& Tuschak 1997) and 907r (5' CCG TCA ATT CMT TTG AGT TT 3') (Muyzer et al. 1993) [M=A/C] (1 pmol $\mathrm{ul}^{-1}$ each); and $1 \mathrm{U}$ of Taq DNA polymerase (Amersham Pharmacia Biotech). DNA templates were prepared by dilution of the purified DNA extracts by 1:100 in Milli-Q water. PCR was performed using the touchdown PCR program of Schäfer \& Muyzer (2001).

DGGE analysis. PCR products were loaded directly onto the DGGE (Denaturing Gradient Gel Electrophoresis) gel. Gels were run at $200 \mathrm{~V}$ for $5 \mathrm{~h}$ in $1 \times$ TAE with a 35 to $70 \%$ denaturating gradient of formamide and urea, using the DCode Universal Mutation detection System (Bio Rad). DNA bands were visualised with ethidium bromide.

The band patterns on the gels were analysed using specially written software. The individual lanes of the DGGE gels were digitised and the background subtracted using the 'rolling disk' algorithm (Sternberg 1983). The major peaks were identified manually and a difference matrix was produced using the Dice algorithm. Clustering was performed using UPGMA (unweighted pair group means with arithmetic averages).

\section{RESULTS}

\section{Sediment characteristics}

Burrow walls had a smooth texture due to tightly compacted muddy sediment and showed a redbrownish colour. Seagrass debris was seen incorporated into the burrow wall. Surface sediment, on the other hand, was light brown while the ambient sediment was in most cases dark grey to black.

Burrow walls had a lower density than surface and ambient sediment, the latter 2 showing similar values (Table 1). In all cases the sediment was characterised as fine sand, showing, however, a lower median grain-

Table 1. Sediment characteristics for surface sediment, burrow wall and ambient sediment from burrows of Pestarella tyrrhena. $\mathrm{Md}=$ median grain size diameter, LOI $=$ organic content as loss-on-ignition, $\mathrm{C}: \mathrm{N}=$ particulate organic carbon to particulate organic nitrogen ratio. Values reported are yearly means \pm SE $(n=4)$

\begin{tabular}{|lcccccc|}
\hline Sediment & $\begin{array}{c}\text { Wet density } \\
\left(\mathrm{g} \mathrm{cm}^{-3}\right)\end{array}$ & $\begin{array}{c}\text { Md } \\
(\mu \mathrm{m})\end{array}$ & $\begin{array}{c}\text { Silt \& clay } \\
(\%)\end{array}$ & Sorting & $\begin{array}{r}\text { LOI } \\
(\%)\end{array}$ & $\begin{array}{c}\text { C:N } \\
(\mathrm{mol}: \mathrm{mol})\end{array}$ \\
\hline Surface & $1.84 \pm 0.01$ & $171 \pm 2$ & $0.8 \pm 0.3$ & Medium & $1.7 \pm 0.2$ & $20 \pm 2$ \\
Burrow wall & $1.44 \pm 0.08$ & $147 \pm 4$ & $19.2 \pm 0.5$ & Poor & $6.3 \pm 1.0$ & $25 \pm 2$ \\
Ambient & $1.84 \pm 0.02$ & $173 \pm 4$ & $1.2 \pm 0.1$ & Medium & $1.6 \pm 0.1$ & $30 \pm 4$ \\
\hline
\end{tabular}

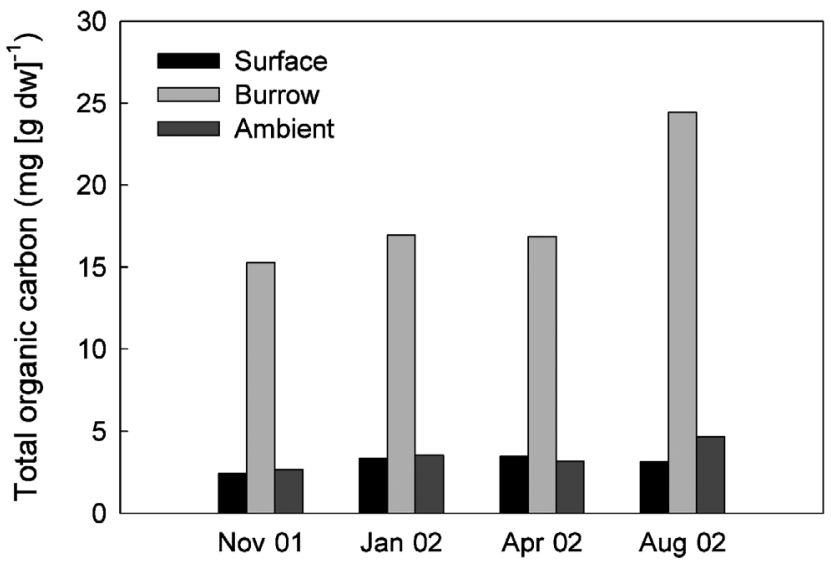

Fig. 1. Seasonal variation in total organic carbon content (mg $\left[\mathrm{g} \mathrm{dw}^{-1}\right.$ ) of surface sediment, burrow wall, and ambient sediment associated with burrows of Pestarella tyrrhena

size diameter in the burrow wall ( $\mathrm{p}<0.05)$. In addition, burrow wall sediment was poorly sorted, having a significantly higher silt and clay fraction (19\%), compared to surface and ambient sediment $(1 \%)(p<0.05)$, which both showed medium sorting.

Yearly mean values of organic content (LOI) in the burrow wall were 3.8 to 4.1 times higher than surface and ambient sediment $(\mathrm{p}<0.05)$ (Table 1$)$. TOC showed the same pattern as LOI. Yearly mean burrow wall TOC was approx. 6 times higher $\left(18.4 \mathrm{mg} \mathrm{g}^{-1}\right)$, than that of surface sediment or ambient sediment $(3.11 \mathrm{mg}$ $\mathrm{g}^{-1}$ and $3.51 \mathrm{mg} \mathrm{g}^{-1}$ respectively) ( $\mathrm{p}<0.05$ ) (Fig. 1). TOC showed a significant correlation with all biopolymeric compounds and number of bacteria but not with phytopigments (Table 2 ). The $\mathrm{C}: \mathrm{N}$ ratio of the burrow wall was intermediate to those of surface and ambient sediment (Table 1).

\section{Microphytobenthic biomass}

Chl a content showed a higher yearly mean value in the burrow wall $\left(3.70 \mu \mathrm{g} \mathrm{g}^{-1}\right)$ than surface sediment $\left(2.70 \mu \mathrm{g} \mathrm{g}^{-1}\right)$ or ambient sediment $\left(0.60 \mu \mathrm{g} \mathrm{g}^{-1}\right)$, although this was statistically significant only with the latter $(\mathrm{p}<0.05)$ due to the large seasonal variations observed. Chl a was higher in surface sediment than in burrow walls in August and lower in January and April, while the 2 sites were similar in the previous November (Fig. 2). Mean phaeo content were highest in the burrow wall $\left(8.10 \mu \mathrm{g} \mathrm{g}^{-1}\right)$ $(p<0.05)$, while much lower values were observed for surface and ambient sediment $\left(0.85\right.$ and $0.60 \mu \mathrm{g} \mathrm{g}^{-1}$ respectively). 
Table 2. Spearman-rank correlation analysis among variables analysed. TOC $=$ total organic carbon, $\mathrm{PRT}=$ protein, $\mathrm{CHO}=$ carbohydrate, $\mathrm{LPD}=$ lipid, $\mathrm{Chl} a=$ chlorophyll $a$, Phaeo $=$ phaeopigments. Number of observations: $\mathrm{n}=12$ with the exception of bacteria where $n=6$. Significant values reported as: ${ }^{*} p<0.05$, ${ }^{* *} \mathrm{p}<0.01$

\begin{tabular}{|lccccccc|}
\hline & TOC & PRT & CHO & LPD & Chl a & Phaeo Bacteria \\
\hline TOC & - & & & & & & \\
PRT & $0.699^{*}$ & - & & & & & \\
CHO & $0.762^{* *}$ & $0.755^{* *}$ & - & & & & \\
LPD & $0.678^{*}$ & 0.545 & $0.895^{* *}$ & - & & & \\
Chl $a$ & 0.398 & 0.237 & $0.594^{*}$ & $0.727^{* *}$ & - & & \\
Phaeo & 0.524 & $0.615^{*}$ & $0.846^{* *}$ & $0.902^{* *}$ & $0.790^{* *}$ & - & \\
Bacteria & $0.828^{*}$ & $0.942^{* *}$ & $0.942^{* *}$ & 0.657 & 0.314 & 0.600 & - \\
\hline
\end{tabular}

The highest yearly mean ratio of chl a to $\mathrm{CPE}$, indicating fresher material, was found for surface sediment (64\%), with a maximum in August (87\%) (Fig. 2). Burrow walls, on the other hand, showed the lowest ratios (33\%), while ambient sediment was intermediate. Overall, microphytobenthic carbon accounted for only a small fraction of TOC in all sediment types. Surface sediment had the highest yearly mean contribution
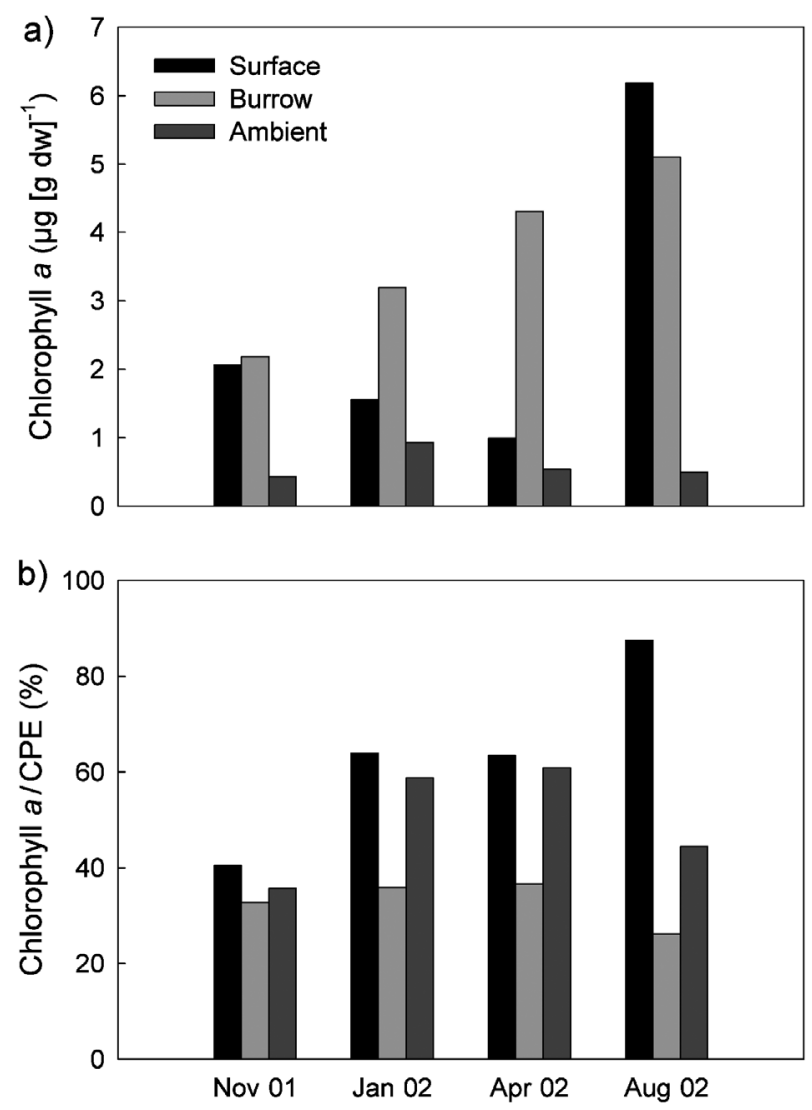

Fig. 2. (a) Seasonal variation in chlorophyll a content $\left(\mu \mathrm{g}\left[\mathrm{g} \mathrm{dw}^{-1}\right)\right.$ and (b) chlorophyll a to total chloroplastic pigments (CPE) (\%) of surface sediment, burrow wall, and ambient sediment associated with burrows of Pestarella tyrrhena
(3.6\%), showing a maximum of $7.9 \%$ in August 2002, while burrow wall and ambient sediment had a mean of 0.7 to $0.8 \%$ (Fig. 3).

\section{Biochemical composition of organic matter}

The 3 sediment types always had significant differences in protein, carbohydrate, and lipid content, with yearly mean being highest at the burrow wall $(p<0.05)$ (Fig. 4). Sediment protein content in the burrow wall was 4.2 and 6.5 times higher than ambient sediment and surface sediment respectively, while for carbohydrates a 11-fold increase was observed at the burrow wall compared to the 2 other sediment types. Burrow wall lipid content was 4.0 and 4.9 times higher than surface and ambient sediment respectively. The contribution of the various biopolymers to TOC was different in the 3 sediment types. Carbohydrates were the most abundant type in the burrows $(25 \%)$, followed by proteins (19\%) and lipids (3\%), while proteins were most important both in the surface (18\%) and the ambient (25\%), whereas lipids made only a small contribution (Fig. 3). Thus, the total identified fraction (PRT+ CHO+LPD) of TOC was highest in the burrow wall $(47 \%)$, followed by ambient sediment $(40 \%)$ and lowest for surface sediment (36\%) (Fig. 3).

\section{Particulate iron}

The total extracted particulate iron pool showed 2 -fold and 3-fold higher concentration in the burrow

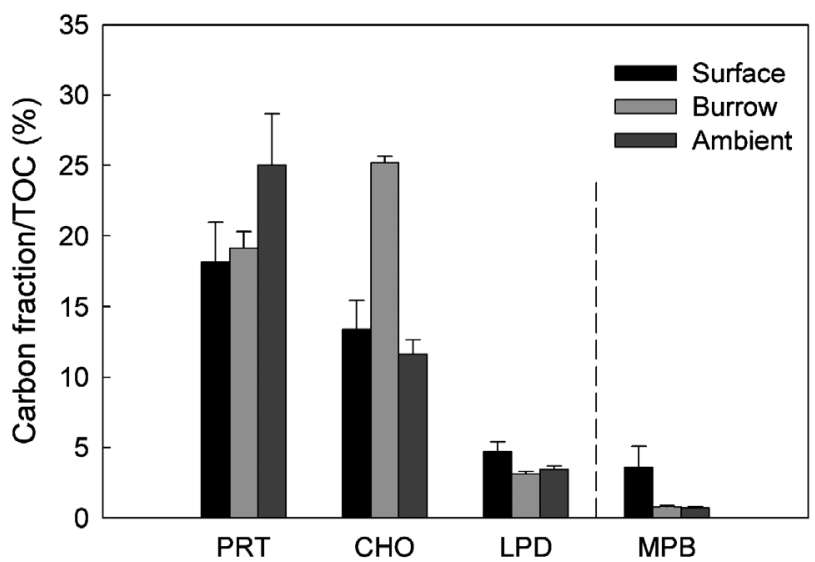

Fig. 3. Yearly mean relative contribution (\%) of proteins (PRT), carbohydrates (CHO), lipids (LPD) and microphytobenthic chlorophyll a (MPB) carbon to total organic carbon (TOC) of surface sediment, burrow wall, and ambient sediment associated with burrows of Pestarella tyrrhena (mean $+\mathrm{SE}, \mathrm{n}=4$ ) 


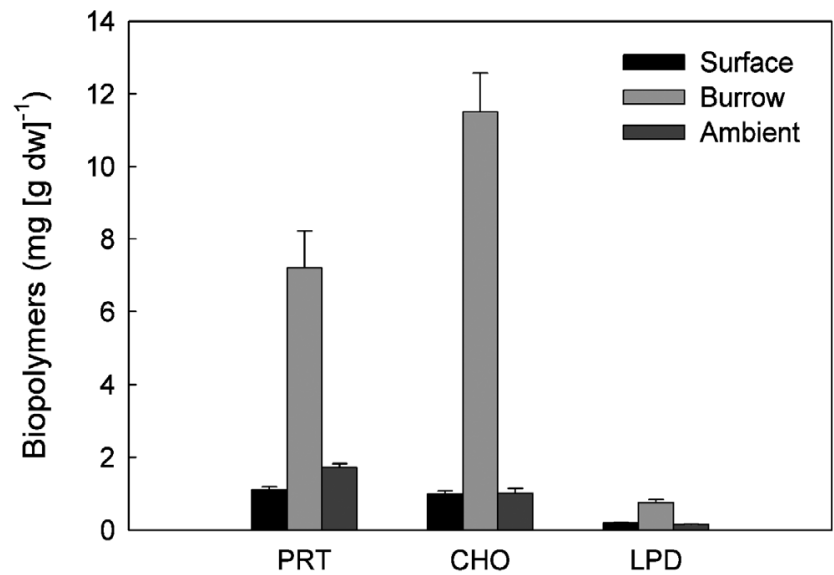

Fig. 4. Yearly mean protein (PRT), carbohydrate $(\mathrm{CHO})$ and lipid (LPD) content $\left(\mathrm{mg}[\mathrm{g} \mathrm{dw}]^{-1}\right.$ ) of surface sediment, burrow wall, and ambient sediment associated with burrows of Pestarella tyrrhena (mean $+\mathrm{SE}, \mathrm{n}=4$ )

wall compared to the ambient and surface sediment respectively ( $p<0.05$ ) (Fig. 5). Fe(III) constituted 62\% of the total iron pool in the burrows, $33 \%$ in the surface sediment, while only small amounts of Fe(III) were found in the ambient sediment (5\%).

\section{Bacterial abundance}

Mean bacterial abundances based on DAPI counts were 1 order of magnitude higher in the burrow wall $\left(4.0 \times 10^{9}\right.$ cells $\left.\mathrm{cm}^{-3}\right)$ than in both surface $\left(4.5 \times 10^{8}\right.$ cells $\left.\mathrm{cm}^{-3}\right)$ and ambient sediment $\left(4.8 \times 10^{8}\right.$ cells $\left.\mathrm{cm}^{-3}\right)(\mathrm{p}<$ 0.01) (Fig. 6). Bacterial abundance was affected by the season, being higher in summer than in winter; however, this was statistically confirmed only for surface and burrow wall sediment $(p<0.05)$.

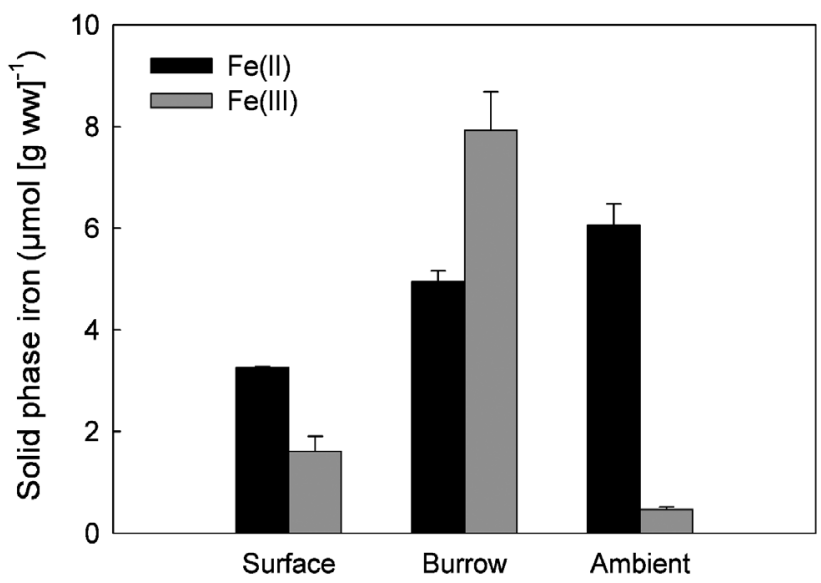

Fig. 5. Particulate Fe pools in surface sediment, burrow wall, and ambient sediment associated with burrows of Pestarella tyrrhena in January 2002 (mean $+\mathrm{SE}, \mathrm{n}=3$ to 4$)$

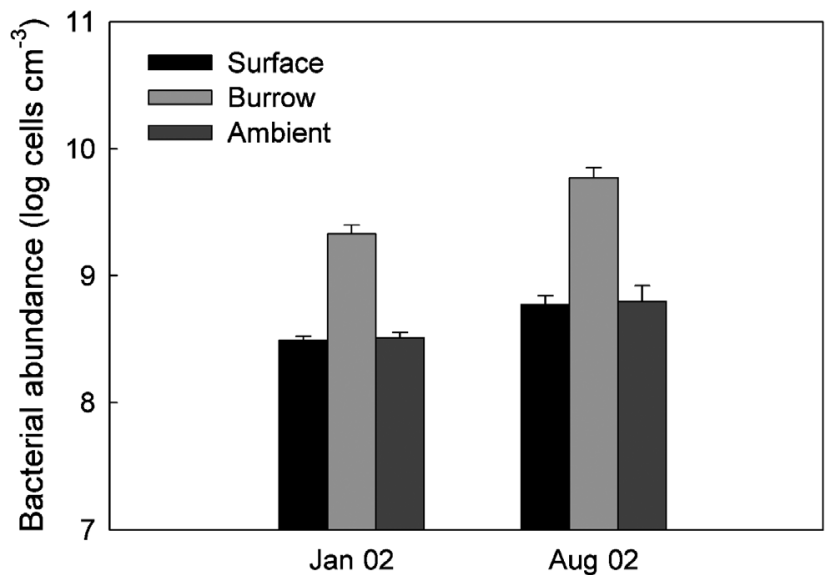

Fig. 6. Bacterial abundance in surface sediment, burrow wall, and ambient sediment associated with burrows of Pestarella tyrrhena (mean $+\mathrm{SE}, \mathrm{n}=3$ )

\section{Bacterial diversity}

Visual inspection of DGGE profiles showed marked changes in the number and position of the bands, suggesting seasonal changes and effects of location (Fig. 7). Cluster analysis of the band patterns showed 2 distinct groupings; the anoxic ambient sediment samples showing the highest similarity (65\%) and the burrow wall sediment samples grouped together with a similarity of $45 \%$. These 2 groups joined together at a similarity of $30 \%$. Surface sediment samples were more variable, suggesting significant bacterial community changes during the course of the year at the sediment-water(air) interface.

\section{DISCUSSION}

\section{Burrow wall characteristics}

Pestarella tyrrhena burrows in Vravrona Bay are plastered with a smooth red/brown layer, consisting of compacted sediment with a much finer grain composition than ambient sediment, as has been reported previously from other thalassinidean burrows (Dobbs \& Guckert 1988, de Vaugelas \& Buscail 1990, Over 1990). This suggests that $P$. tyrrhena is capable of sorting sediment grains; selected fine particles are incorporated into the burrow wall to stabilise the structure, resulting in a lower grain- size homogeneity along burrow walls. Even though particle size selectivity by $P$. tyrrhena has not been studied extensively, such a mechanism during feeding is known for other thalassinidean shrimps with a similar mode of life (Pinn et al. 1998, Stamhuis et al. 1998). Fine particles may also be transported from the overlying water into the burrow during irrigation, 


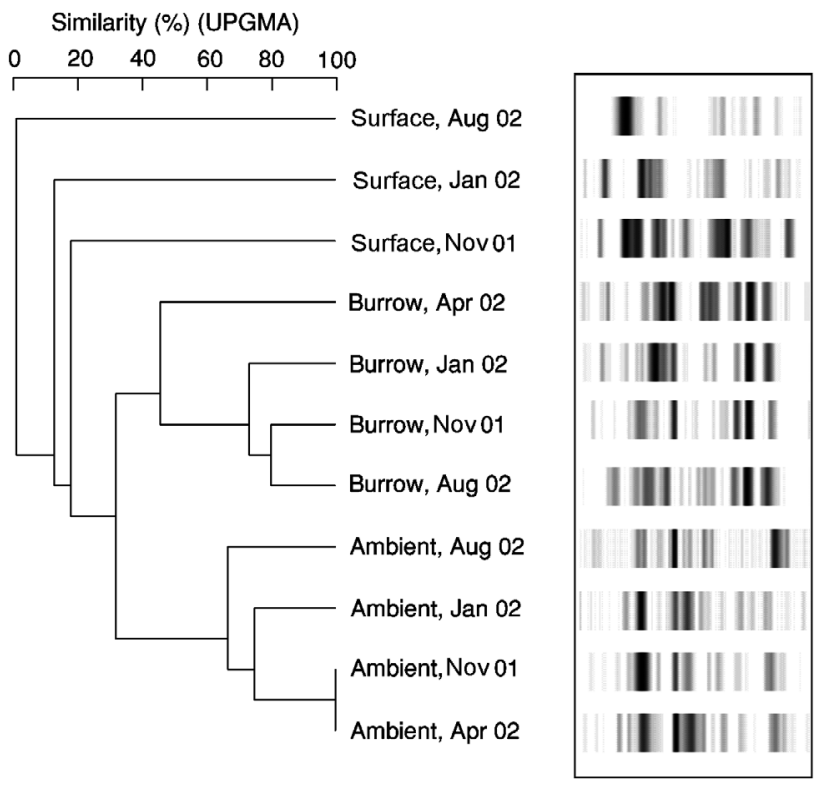

Fig. 7. Clustering by unweighted pair group means with arithmetic averages (UPGMA) of the band patterns obtained by denaturant gradient gel electrophoresis (DGGE) analysis of samples taken around Pestarella tyrrhena burrows. The amount of amplified product obtained for surface sediment from April 2002 was too small to detect the individual bands. Major bands were identified manually from densitometric traces (not shown). The band patterns shown are generated

from the original traces after background subtraction

where they stick to the burrow wall (Dobbs \& Guckert 1988, Kristensen 1988).

A number of previous investigations have not detected any difference between organic matter in burrow walls of thalassinidean shrimps and surrounding sediment (Dworschak 1983, Bird et al. 2000) while others, in accordance with our results, have found significant enrichments (de Vaugelas \& Buscail 1990, Dworschak 2001). Based on Pestarella tyrrhena burrow dimensions determined from in situ studies (Panaritou 1995, Dworschak 2001, P. C. Dworschak pers. comm.) and our TOC measurements, and assuming an equal distribution of organic carbon along the burrow walls (1 mm thickness), we estimate that for the mean population density at Vravrona Bay (63 ind. $\mathrm{m}^{-2}$; Thessalou-Legaki 1987) between 2 and $10 \%$ of the total sedimentary TOC in a given area (depending on burrow length) is located along the burrow walls.

Higher concentrations of trace metals along burrow walls, such as we observed here for iron, have been reported previously (Aller et al. 1983, Aller \& Aller 1986, Over 1990, Gribsholt et al. 2003). This increase may be attributed to a higher proportion of clay particles, allowing for sorption of iron oxides and/or organics (Aller \& Aller 1986, Over 1990). In addition, the elevated iron concentration may result from Fe(II) dif- fusing horizontally from ambient anoxic sediment and subsequent precipitation in the oxic zone of the burrow wall (Aller \& Aller 1986, Over 1990).

\section{Sources of burrow wall organic matter}

Organic matter derived from microalgae (i.e. phytoplankton and microphytobenthos) may constitute the main food source for deposit feeders in coastal environments (MacIntyre et al. 1996). The content of chl a in the burrows of Pestarella tyrrhena was similar to or slightly higher than that in surface sediment, as previously reported for other burrowing shrimps (Dobbs \& Guckert 1988, Kinoshita et al. 2003). One source of chl $a$ in the burrows could be phytoplankton from the overlying water or resuspended microphytobenthic biomass translocated into the burrows by irrigation. Assuming an irrigation rate estimate of $5.8 \mathrm{ld}^{-1}$ ind. $^{-1}$ (Papaspyrou et al. 2004), a mean annual water column chl a concentration of $4.8 \mu \mathrm{g} \mathrm{l}^{-1}$ at Vravrona Bay (S. Papaspyrou et al. unpubl. data) and ignoring degradation, a maximum of $53 \%$ of the chl a in the burrow wall could be attributed to daily transport of microalgae from the overlying water if all $\mathrm{chl} a$ is retained during water passage. Another source of chl $a$ in the burrows could be microphytobenthos buried into the sediment due to sediment reworking, which constantly buries and re-exposes diatoms at the surface. A high benthic microalgal biomass (mainly diatoms) has been observed in the presence of bioturbating infauna even at a depth of $25 \mathrm{~cm}$ (Branch \& Pringle 1987, Andresen \& Kristensen 2002, Katrak \& Bird 2003). However, the overall low contribution (Fig. 4) and the non-significant relationship of autotrophic carbon to TOC (Table 2) for the sediment of Vravrona Bay, indicates that the dominant organic matter sources are other than microalgae.

Infaunal mucous secretions have been suggested as a source of organic enrichment of burrow walls (Aller et al. 1983, Kristensen et al. 1985). Dworschak (1983, 1998) suggested that Pestarella tyrrhena lines vertical sections and roofs of the burrow with a mixture of finegrained material and secreted mucus. In general, the presence or absence of a lining in thalassinidean shrimp burrows is determined to a large extent by the habitat and sediment characteristics (i.e. sediment grain size). Thus, in sandy sediments, a mucus lining is necessary to support the easily collapsing walls of the burrow, whereas this is not usually the case in cohesive muddy sediments (for a review see Dworschak 1983).

Organic enrichment of the burrow wall may also be the result of seagrass detritus accumulation along the burrow wall. Posidonia oceanica detritus, transported from adjacent subtidal areas, are abundant on the intertidal flat of Vravrona Bay. The detritus drifts by 
wave and current action and occasionally, creates large wrack beds on the shore. Drifting seagrass debris is also trapped in the funnel-shaped burrow openings and may fall passively into the galleries or become buried at the surface under sediment ejected from the mound opening (Dworschak 2001, Papaspyrou et al. 2004). This material, together with older detritus already deposited in the sediment and selected by the shrimp, can be seen incorporated into the burrow wall or in burrow chambers, where it is allowed to decompose creating organic hot spots.

Our values for biopolymeric compounds in the sediment, particularly in the burrow walls, were among the highest reported in the literature (Pusceddu et al. 1999, their Table 2). However, the generally low chl a to CPE and protein to carbohydrate ratio (PRT: $\mathrm{CHO}=0.6$ ), as well as the dominance of carbohydrates for the burrow wall of Pestarella tyrrhena at Vravrona Bay, are characteristic of highly oligotrophic or detritic environments (Danovaro et al. 1994, Danovaro 1996, Pusceddu et al. 1999) and indicate the presence of large amounts of aged detritus of relatively low nutritional quality derived from e.g. seagrasses. Dobbs \& Guckert (1988) also found a low chl a to CPE ratio in the burrow wall of Callianassa trilobata, which was attributed to the incorporation of vascular plant debris into the burrow lining.

Only a small fraction of Posidonia oceanica detritus is directly available to benthic consumers for consumption, due to a low nitrogen content and a high content of refractory compounds, such as structural carbohydrates (Velimirov 1987, Danovaro 1996, Pusceddu et al. 1999). The rapid deposition combined with the low nutritional quality of incorporated detritus suggests that the sediment, and the burrow environment in particular, act as an organic matter sink ('detrital trap') (de Vaugelas \& Buscail 1990, Pusceddu et al. 1999, Kinoshita et al. 2003) where the fraction of primary production not directly available to the detritus foodchain accumulates. It therefore appears that organic nitrogen (i.e. protein) is the major limiting element for deposit feeders (Tenore et al. 1984), and that they need to employ other mechanisms to obtain the needed nitrogen. Gardening of bacteria has been proposed as a way to overcome this limitation. Many deposit feeding thalassinidean shrimps, like Pestarella tyrrhena, store seagrass detritus in burrow chambers and burrow walls to decompose (Griffis \& Suchanek 1991, Ziebis et al. 1996, Dworschak 2001), most likely in order to feed on the nitrogen-rich microorganisms (bacteria and meiofauna) growing on this material. These animals typically show 'wall-grazing' behaviour, where sediment is removed from the burrow wall, sorted and part of it (including the microorganisms) ingested, while the remaining is either ejected from the burrow or incorporated again into the wall.

\section{Bacterial abundance and community characteristics}

As for other thalassinidean shrimp burrows (Aller et al. 1983, Branch \& Pringle 1987, Kinoshita et al. 2003), bacterial abundance within burrow walls of Pestarella tyrrhena was significantly higher than at the sediment surface and in adjacent ambient sediment. This is in agreement with Dworschak (2001), who, in addition, found an even higher abundance of bacteria in chambers with seagrass debris inside $P$. tyrrhena burrows than along burrow walls. These results are indicative of a gardening activity. However, little is actually known on what exactly is consumed and utilised for the animal nutrition during 'wall-grazing' by thalassinidean shrimps like $P$. tyrrhena (Griffis \& Suchanek 1991). In addition, the role of gardening and the significance of bacteria as a food source for deposit feeding organisms in general are still a matter for discussion, since bacteria usually represent only a small fraction of the available organic carbon and nitrogen in sediments (Cammen 1980, Danovaro et al. 1994, Danovaro 1996, Andresen \& Kristensen 2002).

The observed differences in the composition and quality of organic matter (i.e. food availability), as well as chemical character between burrow walls and surrounding sediment were expected to affect not only the abundance but also the composition of the bacterial communities. Previous studies based on phospholipid fatty acid compositions have found no or only limited differences in bacterial composition between burrow wall and surrounding sediment for thalassinidean shrimps (Dobbs \& Guckert 1988, Bird et al. 2000). Our results based on more sensitive DGGE profiles, on the other hand, show a clear distinction between molecular fingerprints of bacterial communities from the different parts of Pestarella tyrrhena burrows. Burrow wall and ambient sediment samples always form 2 separate groups, indicating that seasonal differences are less important than location in determining the bacterial community composition. In contrast, there were large and distinct seasonal changes in the community of surface sediment from Vravrona Bay, reflecting large variations in environmental conditions at the sediment-water(air) interface (S. Papaspyrou et al. unpubl. data). Similarly, Lucas et al. (2003) reported that the bacterial composition along the burrow walls of Nereis diversicolor is stable over time and markedly different from the community at the sediment surface. Even though microorganisms along burrow walls have to adapt to the rapidly oscillating redox environment due to the usually intermittent burrow ventilation (Kristensen 1988, Ziebis et al. 1996, Furukawa 2001), our results confirm the idea that infaunal burrows, and ambient sediment, are stable environments over longterm periods compared to surface sediment, which is 
continually disturbed by macrofaunal feeding, and current or wave mediated action (Kristensen 1988). In addition, our results indicate that the bacterial community along burrow walls resembles that of the ambient anoxic sediment more than that of the sediment surface. The same has been observated for burrows of $N$. diversicolor and Nereis virens (S. Papaspyrou et al. unpubl. data). This supports previous suggestions based on physicochemical properties of burrows that (1) burrow walls should not be considered a simple extension of the oxic sediment surface and (2) burrow wall community structure should be significantly different regarding both the microbial ecology and distribution of functional groups (Kristensen et al. 1985, Kristensen 1988, Furukawa 2001).

Infaunal burrows are dynamic systems with intense small-scale gradients that support the growth of complex microbial assemblages. The physicochemical properties of the burrows, their age and the irrigation pattern are amongst the factors that have been shown to affect the composition of the bacterial community along the burrow walls in artificial experimental systems (Marinelli et al. 2002). Further studies are needed to clarify the mechanisms by which Pestarella tyrrhena bioturbation affects the bacterial community composition, which bacterial functional groups are favoured by the burrow environment, and the possible role of bacteria in the recycling of aged detritus and $P$. tyrrhena nutrition.

Acknowledgements. We wish to thank all the friends and colleagues for their help during sample collection. Dr. I. Akoumianaki is acknowledged for priceless advice during the biopolymers analyses. We also acknowledge the valuable comments from 3 anonymous reviewers that helped us improve the manuscript. This work was supported by grants to M.T.-L. by the University of Athens (SARG Grant \# 70/4/3276) and E.K. by the Danish Science Research Foundation (Grant \# 21020463). During this work, S.P. received a PhD scholarship from the Greek State Scholarships Foundation.

\section{LITERATURE CITED}

Aller JY, Aller RC (1986) Evidence for localized enhancement of biological activity associated with tube and burrow structures in deep-sea sediments at the HEBBLE site, western North Atlantic. Deep-Sea Res 33:755-790

Aller RC, Yingst JY, Ullman WJ (1983) Comparative biogeochemistry of water in intertidal Onuphis (Polychaeta) and Upogebia (Crustacea) burrows: temporal patterns and causes. J Mar Res 41:571-604

Andresen M, Kristensen E (2002) The importance of bacteria and microalgae in the diet of the deposit-feeding polychaete Arenicola marina. Ophelia 56:179-196

Ausubel FW, Brent R, Kingston RE, Moore DD, Seidman JG, Struhl K, Smith JA (1995) Short protocols in molecular biology, 3rd edn. John Wiley \& Sons, New York

Bird FL, Boon PI, Nichols PD (2000) Physicochemical and microbial properties of burrows of the deposit-feeding Thalassinidean ghost shrimp Biffarius arenosus (Decapoda: Callianassidae). Estuar Coast Shelf Sci 51:279-291

Bligh EG, Dyer W (1959) A rapid method for total lipid extraction and purification. Can J Biochem Phys 37:911-917

Branch GM, Pringle A (1987) The impact of the sand prawn Callianassa kraussi Stebbing on sediment turnover and on bacteria, meiofauna, and benthic microflora. J Exp Mar Biol Ecol 107:219-235

Buchanan JB (1984) Sediment analysis. In: Holme NA, McIntyre AD (eds) Methods for the study of marine benthos. Blackwell Scientific Publications, Oxford, p 45-61

Cammen LM (1980) The significance of microbial carbon in the nutrition of the deposit feeding polychaete Nereis succinea. Mar Biol 61:9-20

Danovaro R (1996) Detritus-bacteria-meiofauna in a seagrass bed (Posidonia oceanica) of the NW Mediterranean. Mar Biol 127:1-13

Danovaro R, Fabiano M, Boyer M (1994) Seasonal changes of benthic bacteria in a seagrass bed (Posidonia oceanica) of the Ligurian Sea in relation to origin, composition and fate of the sediment organic matter. Mar Biol 119:489-500

De Jonge VE (1980) Fluctuations in the organic carbon to chlorophyll a ratios for estuarine benthic diatom populations. Mar Ecol Prog Ser 2:345-353

de Vaugelas J, Buscail R (1990) Organic matter distribution in burrows of the thalassinid crustacean Callichurus laure, Gulf of Aqaba (Red Sea). Hydrobiologia 207:269-277

Dobbs FC, Guckert JB (1988) Callianassa trilobata (Crustacea: Thalassinidea) influences abundance of meiofauna and biomass, composition, and physiologic state of microbial communities within its burrow. Mar Ecol Prog Ser 45:69-79

Dworschak PC (1983) The biology of Upogebia pussila (Petagna) (Decapoda, Thalassinidea). I.: the burrows. PSZN I: Mar Ecol 4:19-43

Dworschak PC (1987) Feeding behaviour of Upogebia pusilla and Callianassa tyrrhena (Crustacea, Decapoda, Thalassinidea). Investig Pesq 51:421-429

Dworschak PC (1998) The role of tegumental glands in burrow construction by two mediterranean Callianassid shrimps. Senckenb Marit 28:143-149

Dworschak PC (2001) The burrows of Callianassa tyrrhena (Petagna 1792) (Decapoda: Thalassinidea). PSZN I: Mar Ecol 22:155-166

Furukawa Y (2001) Biogeochemical consequences of macrofauna burrow ventilation. Geochem Trans 11:83-91, DOI: 10.1039/b108381c

Gerchakov SM, Hatcher PG (1972) Improved technique for analysis of carbohydrates in sediments. Limnol Oceanogr 17:938-943

Gribsholt B, Kostka JE, Kristensen E (2003) Impact of fiddler crabs and plant roots on sediment biogeochemistry in a Georgia saltmarsh. Mar Ecol Prog Ser 259:237-251

Griffis RB, Suchanek TH (1991) A model of burrow architecture and trophic modes in thalassinidean shrimp (Decapoda: Thalassinidea). Mar Ecol Prog Ser 79:171-183

Katrak G, Bird FL (2003) Comparative effects of the large bioturbators, Trypaea australiensis and Heloecius cordiformis, on intertidal sediments of Western Port, Victoria, Australia. Mar Freshw Res 54:701-708

Kinoshita K, Wada M, Kogure K, Furota T (2003) Mud shrimp burrows as dynamic traps and processors of tidal-flat materials. Mar Ecol Prog Ser 247:159-164

Kostka JE, Luther GW (1994) Partitioning and speciation of solid-phase iron in salt-marsh sediments. Geochim Cosmochim Acta 58:1701-1710 
Kristensen E (1988) Benthic fauna and biogeochemical processes in marine sediments: microbial activities and fluxes. In: Blackburn $\mathrm{TH}$, Sorensen J (eds) Nitrogen cycling in coastal marine environments. John Wiley \& Son, Chichester, p 275-299

Kristensen E, Andersen FO (1987) Determination of organic carbon in marine sediments: a comparison of two CHNanalyser methods. J Exp Mar Biol Ecol 109:15-23

Kristensen E, Jensen MH, Andersen TK (1985) The impact of polychaete (Nereis virens Sars) burrows on nitrification and nitrate reduction in estuarine sediments. J Exp Mar Biol Ecol 85:75-91

Lovley DR, Phillips EJP (1987) Rapid assay for microbially reducible ferric iron in aquatic sediments. Appl Environ Microbiol 53:1536-1540

Lucas FS, Bertru G, Höfle MG (2003) Characterization of freeliving and attached bacteria in sediments colonized by Hediste diversicolor. Aquat Microb Ecol 32:165-174

Marinelli RL, Lovell CR, Wakeham SG, Ringelberg DB, White DC (2002) Experimental investigation of the control of bacterial community composition in macrofaunal burrows. Mar Ecol Prog Ser 235:1-13

Marsh JB, Weinstein WJ (1966) A simple charring method for determination of lipids. J Lipid Res 7:574-576

McIntyre HL, Geider RJ, Miller DC (1996) Microphytobenthos: the ecological role of the 'secret garden' of unvegetated, shallow-water marine habitats. I. Distribution, abundance and primary production. Estuaries 19:186-201

Meadows A (1991) Burrows and burrowing animals: an overview. In: Meadows PS, Meadows A (eds) The environmental impact of burrowing animals. Zoological Society of London, Clarendon Press, Oxford, p 1-11

Miller DN (2001) Evaluation of gel filtration resins for the removal of PCR-inhibitory substances from soils and sediments. J Microbiol Methods 44:49-58

Muyzer G, de Waal E, Uitterlinden AG (1993) Profiling of complex microbial populations by denaturing gradient gel electrophoresis analysis of polymerase chain reactionamplified genes coding for 16s rDNA. Appl Environ Microbiol 59:695-700

Nelson DW, Sommers LE (1975) A rapid and accurate method for estimating organic carbon in soil. Proc Indiana Acad Sci 84:456-462

Over DJ (1990) Trace metals in burrow walls and sediments, Georgia Bight, USA. Ichnos 1:31-41

Overmann J, Tuschak C (1997) Phylogeny and molecular fingerprinting of green sulfur bacteria. Arch Microbiol 167:302-309

Panaritou K (1995) Relations between Callianassa tyrrhena

Editorial responsibility: Søren Rysgaard,

Silkeborg, Denmark
(Decapoda: Thalassinidea) and sediment. MSc thesis, University of Athens, Athens (in Greek)

Papaspyrou S, Thessalou-Legaki M, Kristensen E (2004) Impact of Pestarella tyrrhena on benthic metabolism in sediment microcosms enriched with seagrass and macroalgal detritus. Mar Ecol Prog Ser 281:165-179

Parsons TR, Maita Y, Lalli CM (1984) A manual of chemical and biological methods for seawater analysis. Pergamon Press, Oxford

Pinn EH, Atkinson JA, Rogerson A (1998) Particle size selectivity and resource partitioning in five species of Thalassinidea (Crustacea: Decapoda). Mar Ecol Prog Ser 169:243-250

Porter KG, Feig YS (1980) The use of DAPI for identifying and counting aquatic microflora. Limnol Oceanogr 25:943-948

Pusceddu A, Sarà, Armeni M, Fabiano M, Mazzola A (1999) Seasonal and spatial changes in the sediment organic matter of a semi-enclosed marine system (W-Mediterranean Sea). Hydrobiologia 397:59-70

Reichardt W (1988) Impact of bioturbation by Arenicola marina on microbiological parameters in intertidal sediments. Mar Ecol Prog Ser 44:149-158

Reise K (2002) Sediment mediated species interactions in coastal waters. J Sea Res 48:127-141

Rice DL (1982) The detritus nitrogen problem: new observations and perspectives from organic geochemistry Mar Ecol Prog Ser 9:153-162

Schäfer H, Muyzer G (2001) Denaturing gradient gel electrophoresis in marine microbial ecology. Methods Microbiol 30:425-468

Stamhuis EJ, Videler JJ, de Wilde PAWJ (1998) Optimal foraging in the thalassinidean shrimp Callianassa subterranea. Improving food quality by grain size selection. J Exp Mar Biol Ecol 228:197-208

Sternberg SR (1983) Biomedical image processing. Computer $16: 22-34$

Tenore KR, Hanson RB, McClein J, Maccubin AE, Hodson RE (1984) Change in composition and nutritional value to a benthic deposit feeder of decompositing detritus pool. Bull Mar Sci 35:299-311

Thessalou-Legaki M (1987) Contribution to the study of ecology and biology of Callianassa tyrrhena (Petagna, 1792) (Crustacea, Decapoda, Thalassinidea). PhD thesis, University of Athens, Athens (in Greek)

Velimirov B (1987) Organic matter derived from a seagrass meadow: origin, properties and quality of particles. PSZN I: Mar Ecol 8:143-173

Ziebis W, Forster S, Huettel M, Jørgensen BB (1996) Complex burrows of the mud shrimp Callianassa truncata and their geochemical impact in the sea bed. Nature 382:619-622

Submitted: September 29, 2004; Accepted: December 22, 2004 Proofs received from author(s): February 8, 2005 